The effect of vegetable oils and the fish oil on the fatty acid profile in egg yolks

Utjecaj biljnih ulja i ribljega ulja na profil masnih kiselina $u$ žumanjcima jaja

Kralik, G., Kralik Z., Hanžek, D.

Poljoprivreda/Agriculture

ISSN: $1848-8080$ (Online)

ISSN: 1330-7142 (Print)

https://doi.org/10.18047/poljo.26.2.10

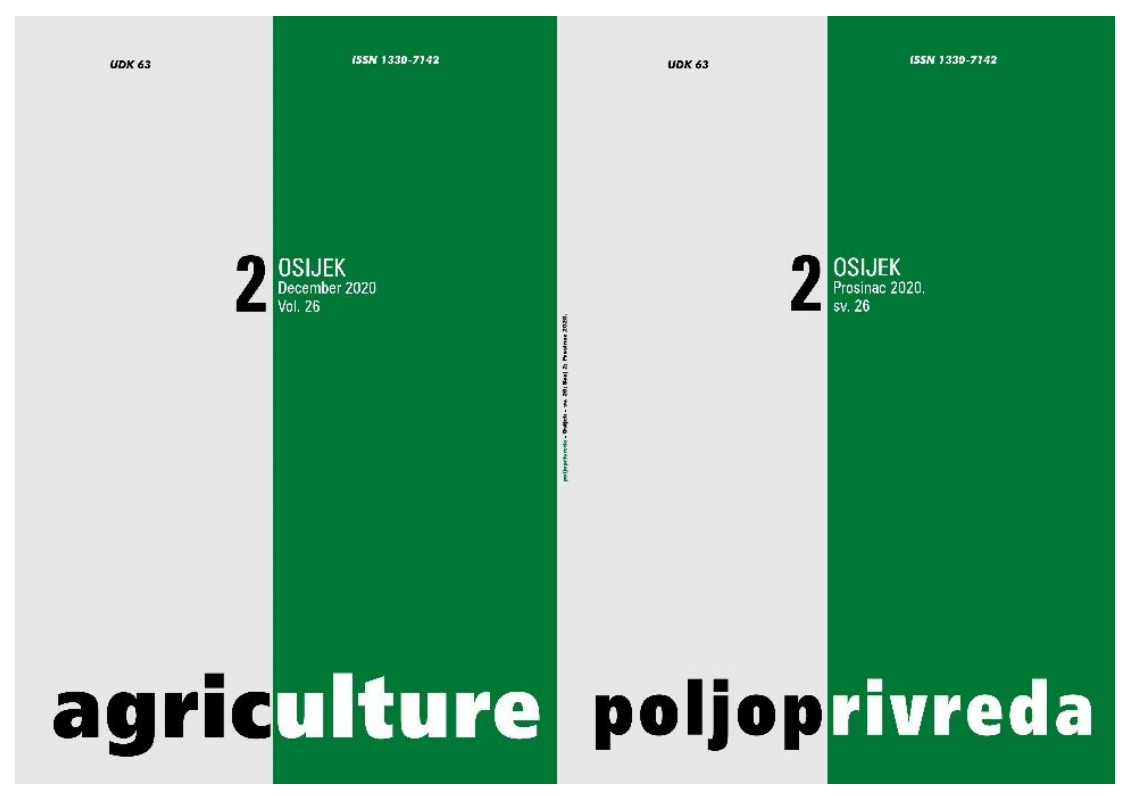

Fakultet agrobiotehničkih znanosti Osijek, Poljoprivredni institut Osijek

Faculty of Agrobiotechnical Sciences Osijek, Agricultural Institute Osijek 


\title{
THE EFFECT OF VEGETABLE OILS AND THE FISH OIL ON THE FATTY ACID PROFILE IN EGG YOLKS
}

Kralik, G. ${ }^{(1,2)}$, Kralik Z. ${ }^{(1,3)}$, Hanžek, D. ${ }^{(1,3)}$

Original scientific paper

Izvorni znanstveni članak

\begin{abstract}
SUMMARY
The paper presents the results of a research in the use of flaxseed (LO) and rapeseed oil (RO) in a combination with fish oil (FO) in the feeding of laying hens and the effect on the fatty acid profile of egg yolks ( $\sum n-3$ PUFA and $\Sigma n-6 / \sum n-3$ PUFA ratio). Nutritional treatments were as follows: C1, C2 = control (5\% soybean oil SO), E1 $=1.5 \% L O+3.5 \% F O, E 2=3.5 \% L O+1.5 \% F O, E 3=1.5 \% R O+3.5 \% F O, E 4=3.5 \%$ $R O+1.5 \%$ FO. Feed mixtures for the laying hens were balanced on the basis of a $17 \%$ crude protein and $11.5 \mathrm{MJ} / \mathrm{kg} \mathrm{ME}$, and the n-6/n-3 PUFA ratio in the mixtures was as follows: C1 13.64, C2 13.10, E1 2.63, E2 1.53, E3 4.84 and E4 6.21. The combination of the flaxseed oil and fish oil in the feed affected the n-6/n-3 PUFA ratio, making it narrower when compared to the combination of rapeseed oil and the fish oil. The control feed C1 and C2 contained only ALA 3.12 and $4.08 \%$, being without the EPA and DHA fatty acids. The analysis of the fatty acid profiles in egg yolks demonstrated that the eggs contained 1.16 and $1.26 \%$ of DHA in addition to ALA, which means that, although in the small amounts, the DHA was synthesized and deposited in the eggs by the laying hens. The following proportions of n-3 PUFAs were found in the eggs of the experimental groups: E1 6.51\%, E2 8.30\%, E3 5.17\%, and E4 3.54\%. The $n-6 / n-$ 3 PUFA ratio in egg yolks decreased from 9.67 and 11.85 (control groups) to 3.08 and 2.57, respectively, for the flaxseed and fish oil treatments and 4.25 and 6.95 for the rapeseed and fish oil treatment. The studies have demonstrated a more efficient deposition of the n-3 PUFAs in the yolks of the E1 and E2 groups, although the ALA was most abundantly present in the total n-3 PUFAs.
\end{abstract}

Keywords: egg, FA, ALA, EPA, DHA, n-6/n-3 PUFA ratio

\section{INTRODUCTION}

Eggs are an excellent source of quality proteins and lipids (phospholipids and polyunsaturated fatty acids), as well as of the minerals and vitamins (Miranda et al., 2015). The market eggs differ between the producers in a physical quality and chemical composition (Kralik et al., 2017a). A consumer interest has increased not only due to a nutritional and dietary value but also due to a biofunctional value of eggs (Bubel et al., 2011). A composition modification of diets for the laying hens using the vegetable and animal oils can manipulate the lipid content in egg yolks (Kralik et al., 2005, 2008a, 2008b, 2018; Yalçın et al., 2010; Petrović et al., 2012; Ehr et al., 2017). The $n-3$ polyunsaturated fatty acids (n-3 PUFAs), such as $\alpha$-linolenic (ALA), eicosapentaenoic (EPA), and docosahexaenoic (DHA) acids, have a significant biologi- cal effect on health. ALA is a biological precursor of the long-chain fatty acids (LC-PUFA n-3; Meyer et al., 2003; Fraeye et al., 2012). The conversion of ALA into the EPA and DHA in humans is only $0.05-0.40 \%$, and therefore needs to be ingested by food (Hussein et al., 2005; Burdge, 2006). This fact arouses researchers' interest for the most efficient enrichment of products with the n-3 PUFA. The eggs are a suitable product that can be enriched with nutrients (Shapira, 2010). The eggs' nutrient content can be altered by a simple technological process,

(1) Prof. Emer. Dr. Dr. h. c. Gordana Kralik - Josip Juraj Strossmayer University of Osijek, Scientific Center of Excellence for Personalized Health Care, Trg Svetog Trojstva 3, 31000 Osijek, Croatia, (2) Nutricin j. d. o. o. Darda, Braće Radića 6, 31326 Darda, Croatia, (3) Assoc. Prof. Zlata Kralik (zlata.kralik@fazos.hr), Danica Hanžek, Mag. Eng. Agr. - Josip Juraj Strossmayer University of Osijek, Faculty of Agrobiotehnical Sciences Osijek, Vladimira Preloga 1, 31000 Osijek, Croatia 
adding certain fodders or ingredients into the laying hens feed (Zaheer, 2015). The free-range eggs contain six times more n-3 PUFAs when compared to the cage eggs (Scheideler and Lewis, 1997). Our research manifeste the influence of the flaxseed and rapeseed oil use in a combination with the fish oil on the fatty acid profile, especially the n-3 PUFA content, as well as a $\Sigma n-6 / \Sigma n-3$ PUFA ratio in the lipids of hen egg yolks.

\section{MATERIAL AND METHODS}

\section{Experimental diet and experimental design}

The paper presents our experience in researching the use of the flaxseed and rapeseed oil in a combination with fish oil while enriching the eggs with the n-3 PUFA. Two separate experiments were conducted with the commercial TETRA SL laying hens, housed in the enriched cages and being in the $31^{\text {st }}$ month of production. Technological and microclimatic conditions met the requirements of these hybrid laying hens. The diets have been balanced at $17 \%$ of crude protein and
11.60 MJ ME/kg in the experiments 1 and 2. In the first experiment (three groups of 45 laying hens in five repetitions), $5 \%$ of soybean oil ( $\mathrm{SO}$ ) was used in the control group $\mathrm{C} 1$, whereas the combinations of flaxseed and fish oil were used: $E 1=1.5 \%$ of linseed oil (LO) $+3.5 \%$ of fish oil (FO) in the experimental groups E1 and E2, and $\mathrm{E} 2=3.5 \%$ of linseed oil (LO) $+1.5 \%$ of fish oil (FO). A combination of rapeseed and fish oil was used in the second experiment (three groups with 45 laying hens in five repetitions) instead of the flaxseed oil, as follows: $\mathrm{E} 3=1.5 \%$ of the rapeseed oil $(\mathrm{RO})+3.5 \%$ of fish oil $(\mathrm{FO})$, i.e., $\mathrm{E} 4=3.5 \%$ of the rapeseed oil $(\mathrm{RO})+1.5 \%$ of fish oil (FO), whereas the control diet C2 also contained $5 \%$ of soybean oil (SO). Table 1 figures the composition of the basic diet, modified for the research purposes, in different vegetable and fish oil combinations.

Feeding and watering were ad libitum. The experiments lasted for 35 days. After the laying hens were fed by the modified diets for five weeks, the egg samples from the $1^{\text {st }}$ and the $2^{\text {nd }}$ experiment were analyzed to detect the fatty acid content.

Table 1. Composition of basic diet for the laying hens

Tablica 1. Sastav osnovnih smiesa za kokoši nesilice

\begin{tabular}{|l|r|l|r|}
\hline Ingredients - Sastojci & $\%$ & $\begin{array}{l}\text { Calculated composition } \\
\text { Izračunan sastav }\end{array}$ & $\%$ \\
\hline Corn - Kukuruz & 47.86 & Crude protein - Sir. proteini & 17.00 \\
Toasted soybean - Tostirana soja & 20.02 & Crude fat - Sir. mast & 8.61 \\
Soybean cake - Sojina pogača & 4.00 & Crude fiber - Sir. vlaknina & 4.97 \\
Sunflower cake - Suncokretova pogača & 6.65 & Ash - Pepeo & 14.57 \\
Dehydrated alfalfa - Dehidrirana djetelina & 3.80 & Lysine - Lizin & 0.15 \\
Limestone - Vapnenac & 11.23 & Methionine - Metionin & 0.45 \\
Monocalcium phosphate - Monokalcijev fosfat & 1.45 & Tryptophane - Triptofan & 0.20 \\
Oil' - Ulje & 5.00 & Arginine - Arginin & 0.20 \\
Salt - Sol & 0.36 & Ca & 1.39 \\
Methionine - Metionin & 0.13 & Total P - Ukupni P & 0.65 \\
Vitamin-mineral premix ${ }^{2}$ - Vitaminsko-mineralni & 0.50 & Available P - Iskoristivi P & 0.38 \\
premiks & 100.00 & ME, MJ/kg & 11.60 \\
\hline Total - Ukupno &
\end{tabular}

${ }^{1}$ Diets differed in the content: $\mathrm{C} 1$ and $\mathrm{C} 2$ groups $=5 \%$ of SO, E1 group 1.5\% of LO $+3.5 \%$ of FO; E2 group $=3.5 \%$ of LO + 1.5\% of F0, E3 group $=1.5 \%$ of RO + $3.5 \% \mathrm{FO} ; \mathrm{C} 4$ group $=3.5 \%$ of $\mathrm{RO}+1.5 \%$ of $\mathrm{FO}$

${ }^{2}$ Premix (1 kg) contained: vitamin A 2,200 IU, vitamin $D_{3} 400 \mathrm{IU}$, vitamin $E_{3} 3000 \mathrm{mg} / \mathrm{kg}$, vitamin $\mathrm{K}_{3} 400 \mathrm{mg} / \mathrm{kg}$, vitamin $\mathrm{B}_{1} 400 \mathrm{mg} / \mathrm{kg}$, vitamin $\mathrm{B}_{2} 800 \mathrm{mg} / \mathrm{kg}$, nicotinic acid $6 \mathrm{mg} / \mathrm{kg}$, calcium panthotenate $1.6 \mathrm{mg} / \mathrm{kg}$, vitamin $B_{6} 700 \mathrm{mg} / \mathrm{kg}$, vitamin $B_{12} 4 \mathrm{mg} / \mathrm{kg}$, folic acid $150 \mathrm{mg} / \mathrm{kg}$, biotin $10 \mathrm{mg} / \mathrm{kg}$, choline chloride $80 \mathrm{mg} /$ $\mathrm{kg}$, vitamin C $4 \mathrm{mg} / \mathrm{kg}$, methionine $40 \mathrm{mg} / \mathrm{kg}$, iodine $160 \mathrm{mg} / \mathrm{kg}$, manganese $13.6-18.4 \mathrm{mg} / \mathrm{kg}$, zinc $12 \mathrm{mg} / \mathrm{kg}$, cobalt $48 \mathrm{mg} / \mathrm{kg}$, iron $5 \mathrm{mg} / \mathrm{kg}$, copper $500 \mathrm{mg} / \mathrm{kg}$, selenium $30 \mathrm{mg} / \mathrm{kg}$, $\beta$-apo ester carotene acid $200 \mathrm{mg} / \mathrm{kg}$, canthaxanthin $600 \mathrm{mg} / \mathrm{kg}$, and a plant base up to $1 \mathrm{~kg}$

\section{Fatty acid analysis}

Fatty acid profile in the feed components (oils), feed, and eggs was determination by the Csapo et al. (1986) method, as follows: the amount of $0.35 \mathrm{~g}$ of the dried samples was weighed into a flask, and $8 \mathrm{ml}$ of concentrated hydrochloric acid was added and boiled for 60 min. After chilling, $7 \mathrm{ml}$ of ethanol was added, then $15 \mathrm{ml}$ of diethyl ether followed, with a one-minute shaking. The next extraction was the one with $15 \mathrm{ml}$ of benzene (b.p. $<60^{\circ} \mathrm{C}$ ). After a phase separation, an organic phase contained about $150-200 \mathrm{mg}$ of fat was separated and evaporated under a vacuum on a rotadest. Then, $4 \mathrm{ml}$ of $0.5 \mathrm{M}$ sodium hydroxide was added into methanol and boiled in a water bath for five minutes. Thereafter, $4 \mathrm{ml}$ of $14 \%$ boron trifluoride was added into methanol and boiled for three minutes, followed by an addition 
of $4 \mathrm{ml}$ of $\mathrm{n}$-hexane. It was boiled for one minute, and then the organic phase was brought to the neck of the flask with a saturated sodium chloride solution. When the phases separated, the samples were taken from the organic phase, dried using the sodium sulfate, and were used for the analysis. The fatty acid methyl esters (FAMEs) were separated on a $10 \times 0.25 \mathrm{~mm}$ wall, coated by an open tubular (WCOT) column, equipped with the CP-SIL 88 (FAME) stationary phase. The quantitation of FAMESs was obtained by a flame ionization detector (FID) at $270^{\circ} \mathrm{C}$. The temperature of the splitter injector was $270^{\circ} \mathrm{C}$, and the carrier gas was helium, with the head pressure of $235 \mathrm{kPa}$. The oven temperature was programmed from $140^{\circ} \mathrm{C}(10 \mathrm{~min})$, with a $10^{\circ} \mathrm{C} / \mathrm{min}$ increase to $235^{\circ} \mathrm{C}$ (26 min). The injected volume varied between 0.5 and $2 \mu \mathrm{l}$. The instrument used was the Chrompack CP 9000 gas chromatograph (Chrompack B.V., The Netherlands, Middleburg). Individual acids in diets and yolk lipids are expressed as a percentage of total fatty acids. The formula (Stibilj et al., 1999) was used to calculate the egg fatty acids $\mathrm{mg} / 100 \mathrm{~g}$ :

$$
\text { g FA } 100 \mathrm{~g}^{-1} \text { egg }=\% \text { total fat egg } \times 0.83 \times \% \text { FA } 100^{-1}
$$

where 0.83 is the factor expressing the FA fraction in the total fat egg.

A fatty acid analysis was conducted for the two samples of feed and oil and ten samples of eggs per group. Table 2 figures the fatty acid profiles in flaxseed, fish, rapeseed and soybean oil.

Table 2. The content of fatty acids in oils (\% of total fatty acids, $\bar{x}$ )

Tablica 2. Sadržaj masnih kiselina u uljima (\% u ukupnim masnim kiselinama, $\bar{x}$ )

\begin{tabular}{|c|c|c|c|c|}
\hline $\begin{array}{l}\text { Fatty acid } \\
\text { Masna kiselina }\end{array}$ & $\begin{array}{l}\text { Linseed oil (LO) } \\
\text { Laneno ulje (LO) }\end{array}$ & $\begin{array}{c}\text { Fish oil (F0) } \\
\text { Riblje ulje (FO) }\end{array}$ & $\begin{array}{l}\text { Rapeseed oil (RO) } \\
\text { Repičino ulje (RO) }\end{array}$ & $\begin{array}{l}\text { Soybean oil (SO) } \\
\text { Sojino ulje (SO) }\end{array}$ \\
\hline$\sum S F A$ & 11.23 & 38.90 & 13.20 & 7.14 \\
\hline$\sum$ MUFA & 19.04 & 26.06 & 51.23 & 65.57 \\
\hline$\sum n-6$ PUFA & 14.90 & 7.00 & 20.96 & 20.66 \\
\hline ALA (C18:3n-3) & 54.82 & 2.45 & 8.93 & 6.63 \\
\hline EPA $(20: 5 n-3)$ & - & 7.15 & - & - \\
\hline DHA (C22:6n-3) & - & 18.44 & - & - \\
\hline$\sum$ n-3 PUFA & 54.82 & 28.04 & 8.93 & 6.63 \\
\hline$\sum_{n-6}$ PUFA $/ \sum$ n-3 PUFA & 0.27 & 0.26 & 2.35 & 3.11 \\
\hline
\end{tabular}

Table 3 figures the percentages of $\Sigma$ SFA, $\Sigma$ MUFA and $\Sigma \mathrm{n}-6$ PUFA in the laying hens' diets. The ALA, EPA, and DHA, as well as the $\Sigma n-3$ PUFA and $\Sigma n-6$ PUFA/ $\Sigma$ n-3 PUFA ratio, are shown separately.The fatty acid composition of a diet depended on the type and concentration of oils. The EPA and DHA were not detected in the control diets, unlike the experimental diets.

Table 3. The content of fatty acids in diets (\% of total fatty acids, $\bar{x}$ )

Tablica 3. Sadržaj masnih kiselina u hrani (\% ukupnih masnih kiselina, $\bar{x}$ )

\begin{tabular}{|c|c|c|c|c|c|c|}
\hline $\begin{array}{l}\text { Fatty acid } \\
\text { Masna kiselina }\end{array}$ & C1 group & E1 group & E2 group & C2 group & E3 group & E4 group \\
\hline$\Sigma$ SFA & 20.43 & 21.39 & 19.45 & 17.41 & 20.50 & 19.38 \\
\hline$\Sigma$ MUFA & 33.66 & 23.42 & 25.24 & 25.04 & 31.13 & 27.42 \\
\hline$\sum \mathrm{n}-6$ PUFA & 42.57 & 40.00 & 33.17 & 53.46 & 39.79 & 45.67 \\
\hline ALA (C18:3n-3) & 3.12 & 10.36 & 17.67 & 4.08 & 4.06 & 4.85 \\
\hline EPA $(20: 5 n-3)$ & - & 1.64 & 1.45 & - & 1.41 & 0.83 \\
\hline DHA (C22:6n-3) & - & 3.19 & 2.63 & - & 2.75 & 1.67 \\
\hline$\sum n-3$ PUFA & 3.12 & 15.19 & 21.75 & 4.08 & 8.22 & 7.35 \\
\hline$\Sigma \mathrm{n}-6$ PUFA/ $\Sigma \mathrm{n}-3$ PUFA & 13.64 & 2.63 & 1.53 & 13.10 & 4.84 & 6.21 \\
\hline
\end{tabular}

¿SFA (C14:0+C15:0+C16:0+C17:0+C18:0+C20:0+C22:0)

IMUFA (C16:1+C17:1+C18:1n9+C20:1n9+C22:1n9)

$\sum n-6$ PUFA (C18:2n6+C18:3n6+C20:2n6+C20:3n6+C20:4n6+C22:2n6)

a, b, c $(P<0.05) ;{ }^{x, z}(P<0.01) ; A, B, C(P<0.001)$

Dietary treatments: $\mathrm{C} 1=5 \% \mathrm{SO}, \mathrm{E} 1=1.5 \% \mathrm{LO}+3.5 \% \mathrm{FO} ; \mathrm{E} 2=3.5 \% \mathrm{LO}+1.5 \% \mathrm{FO} ; \mathrm{C} 2=5 \% \mathrm{SO}, \mathrm{E} 3=1.5 \% \mathrm{RO}+3.5 \% \mathrm{FO} ; \mathrm{E} 4=3.5 \% \mathrm{RO}+1.5 \% \mathrm{FO}$ 


\section{Statistical analysis}

The research results were processed in the Statistica for Windows, version 13.3. (StatSoft Inc., 2017). A data analysis was conducted using a descriptive statistics (mean $-\bar{x}$ and standard deviation - sd) and an analysis of variance (ANOVA), and when the $P$ value was statistically significant, the differences between groups were tested by Fisher's LSD test.

\section{RESULTS AND DISCUSSION}

The results (Table 2) figured that the flaxseed oil was rich in the ALA (54.82\%) but did not contain the EPA and DHA. The $\Sigma n-6$ PUFA/ $\Sigma$ n-3 PUFA ratio was very narrow $(0.27)$. The rapeseed oil was rich in MUFA $(51.23 \%)$, especially in the oleic acid $(O A, C 18: 1 n 9)$. The fish oil contained a high share of SFA $(38.90 \%)$ and DHA $(18.44 \%)$. The sum of the n-3 PUFA in the linseed oil was $54.97 \%, 8.93 \%$ in the rapeseed oil, $28.04 \%$ in the fish oil, and $6.63 \%$ in the soybean oil. The $\Sigma n-6$ PUFA/ $\Sigma n-3$ PUFA ratio in the rapeseed oil was 3.35 , in the soybean oil 3.11 , and 0.26 in fish oil approaching the flaxseed oil by this value. From a biological-functional aspect, the EPA and DHA are most important in the $\Sigma n-3$ PUFA structure, and the fish oil contained both of these fatty acids (EPA 7.15\%, DHA 18.34\%). Frölich and Rice (2005) stated that the rapeseed oil is richest in oleic acid $(56 \%)$, followed by the linoleic $(24.2 \%)$ and linolenic acid $(6.5 \%)$. Laca et al. (2009) pointed out that the flaxseed contained $50.9 \%$ of ALA. Faitarone et al. (2016) state that the flaxseed oil contains $50.16 \%$ of linolenic acid, and the soybean oil contains $56.44 \%$ of linoleic acid, unlike the rapeseed oil, which contains the significant amounts of oleic acid (45.17\%) and linoleic acid (36.57\%).

Mariod et al. (2015) and Brelaz et al. (2019) stated that the fish oil is a rich source of n-3 PUFA and a poor source of $n-6$ PUFA, and that its addition to the laying hens' feed resulted in a significant increase of the n-3 PUFA, whereby this oil use is limited due to an undesirable egg odor. Margeta et al. (2019) highlighted a connection of the nutricin used to enrich the eggs and the sensory properties.

Tables 4 and 5 figure the results of the egg yolks' fatty acid content study in the $1^{\text {st }}$ and in the $2^{\text {nd }}$ experiment. The addition of vegetable oils, flaxseed, and rapeseed in a combination with the fish oil added to the laying hens' diets ahs significantly changed the fatty acid profile in the egg yolks of the experimental group if compared to the control ones. The fatty acid analyses' results were presented as a percentage of total fatty acids and as a mg of FA/100 $\mathrm{g}$ of egg (Stibilj et al., 1999; Weill et al., 2002).

Table 4. The influence of the linseed and fish oil on the fatty acids content in the egg yolks in the $\mathbf{1}^{\text {st }}$ experiment Tablica 4. Utjecaj lanenoga i ribljeg ulja na sadržaj masnih kiselina u žumanjcima jaja 1. pokusa

\begin{tabular}{|c|c|c|c|c|c|c|}
\hline \multirow{2}{*}{$\begin{array}{l}\text { Fatty acid } \\
\text { Masna kiselina }\end{array}$} & $\begin{array}{l}\text { C1 group } \\
(\bar{x} \pm s d)\end{array}$ & $\begin{array}{l}\text { E1 group } \\
(\bar{x} \pm s d)\end{array}$ & $\begin{array}{l}\text { E2 group } \\
(\bar{x} \pm s d)\end{array}$ & $\begin{array}{l}\text { C1 group } \\
(\bar{x})\end{array}$ & $\begin{array}{l}\text { E1 group } \\
(\bar{x})\end{array}$ & $\begin{array}{l}\text { E2 group } \\
(\bar{x})\end{array}$ \\
\hline & \multicolumn{3}{|c|}{$\begin{array}{l}\% \text { of } \mathrm{FA} \text { in the total } \mathrm{FA} \\
\text { e kiseline } u \text { ukupnim masnim kiselinama }\end{array}$} & \multicolumn{3}{|c|}{$\begin{array}{c}\mathrm{mg} \text { of } \mathrm{FA} / 100 \mathrm{~g} \text { of } \mathrm{egg} \\
\text { mg masne kiseline } / 100 \mathrm{~g} \text { jajeta }\end{array}$} \\
\hline$\Sigma S F A$ & $27.41 \pm 0.84^{C}$ & $32.64 \pm 0.55^{A}$ & $30.38 \pm 0.38^{B}$ & 2297.78 & 2736.21 & 2546.76 \\
\hline$\Sigma$ MUFA & $46.66 \pm 0.84$ & $40.66 \pm 0.99$ & $31.84 \pm 1.97$ & 3911.50 & 3408.53 & 2669.15 \\
\hline$\sum n-6$ PUFA & $23.41 \pm 0.91$ & $20.10 \pm 1.21$ & $21.33 \pm 1.94$ & 1962.46 & 1684.98 & 1788.09 \\
\hline ALA (C18:3n-3) & - & $3.25 \pm 0.53^{b}$ & $5.18 \pm 0.47^{a}$ & - & 272.45 & 434.24 \\
\hline $\operatorname{EPA}(20: 5 n-3)$ & $1.26 \pm 0.04$ & $0.27 \pm 0.02$ & $0.22 \pm 0.01$ & 105.62 & 22.63 & 18.44 \\
\hline DHA (C22:6n-3) & $1.16 \pm 0.07$ & $2.99 \pm 0.06$ & $2.90 \pm 0.75$ & 97.24 & 250.65 & 243.11 \\
\hline$\Sigma \mathrm{n}-3$ PUFA & $2.42 \pm 0.16^{\mathrm{C}}$ & $6.51 \pm 0.54^{\mathrm{B}}$ & $8.30 \pm 0.44^{A}$ & 202.86 & 545.73 & 695.79 \\
\hline$\Sigma n-6$ PUFA/ $\Sigma$ n-3 PUFA & $9.67 \pm 0.51^{a}$ & $3.08 \pm 0.23^{b}$ & $2.57 \pm 0.25^{b}$ & 9.67 & 3.08 & 2.57 \\
\hline
\end{tabular}

¿SFA (C14:0+C15:0+C16:0+C17:0+C18:0+C20:0+C22:0)

EMUFA (C16:1+C17:1+C18:1n9+C20:1n9+C22:1n9)

$\Sigma n-6$ PUFA (C18:2n6+C18:3n6+C20:2n6+C20:3n6+C20:4n6+C22:2n6)

$a, b, c(P<0.01) ; A, B, C(P<0.001)$

Dietary treatments: $\mathrm{C} 1=5 \%$ of $\mathrm{SO}, \mathrm{E} 1=1.5 \%$ of $\mathrm{LO}+3.5 \%$ of FO; E2 $=3.5 \%$ of $\mathrm{LO}+1.5 \%$ of FO

The Table 4 data the statistically highly significant differences in the shares of $\Sigma$ SFA and the $\Sigma n-3$ PUFA $(P<0.001)$, whereas the significant differences were found out in the share of ALA and the $\Sigma n-6$ PUFA/ $\Sigma n-3$ PUFA ratio $(P<0.01)$ between the egg groups. The highest share of $\Sigma$ n-3 PUFA in the total fatty acids $(8.30 \%)$ was recorded in the E2 group eggs, being 3.42 times higher when compared to the control $\mathrm{C} 1$ group.
While adding the rapeseed and fish oil into the laying hens' diet (Table 5), the share of ALA $(2.31 \%$ and $1.21 \% ; \mathrm{P}<0.001)$ and DHA $(2.64 \%$ and $2.23 \% ; \mathrm{P}<0.01)$ in the E3 and E4 egg groups was significantly increased in relation to the control C2 group. The highest share of the $\Sigma \mathrm{n}-3$ PUFA was achieved in the lipids of the E3 egg group. 
Table 5. The influence of the rapeseed oil and the fish oil on the fatty acids content in egg yolks of the $2^{\text {nd }}$ experiment Tablica 5. Utjecaj repičina i ribljeg ulja na sadržaj masnih kiselina u žumanjcima jaja 2. pokusa

\begin{tabular}{|c|c|c|c|c|c|c|}
\hline \multirow[t]{2}{*}{$\begin{array}{l}\text { Fatty acid } \\
\text { Masna kiselina }\end{array}$} & $\begin{array}{l}\text { C2 group } \\
(\bar{x} \pm s d)\end{array}$ & $\begin{array}{l}\text { E3 group } \\
(\bar{x} \pm s d)\end{array}$ & $\begin{array}{l}\text { E4 group } \\
(\bar{x} \pm s d)\end{array}$ & $\begin{array}{l}\text { C2 group } \\
(\bar{x})\end{array}$ & $\begin{array}{l}\text { E3 group } \\
(\bar{x})\end{array}$ & $\begin{array}{l}\text { E4 group } \\
(\bar{x})\end{array}$ \\
\hline & \multicolumn{3}{|c|}{$\begin{array}{l}\text { \% of FA in the total FA } \\
\% \text { masne kiseline u ukupnim masnim kiselinama }\end{array}$} & \multicolumn{3}{|c|}{$\begin{array}{c}\mathrm{mg} \text { of } \mathrm{FA} / 100 \mathrm{~g} \text { of egg } \\
\text { mg masne kiseline/100 g jajeta }\end{array}$} \\
\hline$\Sigma$ SFA & $31.65 \pm 0.05$ & $31.18 \pm 0.84$ & $31.46 \pm 0.34$ & 2653.22 & 2613.82 & 2637.29 \\
\hline$\Sigma$ MUFA & $36.95 \pm 0.84^{B}$ & $40.66 \pm 1.26^{\mathrm{A}}$ & $40.72 \pm 2.53^{\mathrm{A}}$ & 3097.52 & 3408.53 & 3413.56 \\
\hline$\sum n-6$ PUFA & $28.80 \pm 1.04^{\mathrm{a}}$ & $21.96 \pm 1.96^{b}$ & $24.61 \pm 3.60^{b}$ & 2414.30 & 1840.91 & 2063.06 \\
\hline ALA (C18:3n-3) & $1.17 \pm 0.89^{B}$ & $2.31 \pm 0.15^{\mathrm{A}}$ & $1.21 \pm 0.13^{B}$ & 98.08 & 193.65 & 101.43 \\
\hline EPA (20:5n-3) & $\operatorname{Tr}^{*}$ & $0.22 \pm 0.13$ & $0.10 \pm 0.09$ & $\operatorname{Tr}^{*}$ & 18.44 & 8.38 \\
\hline DHA (C22:6n-3) & $1.26 \pm 0.05^{x}$ & $2.64 \pm 0.42^{2}$ & $2.23 \pm 0.54^{z}$ & 105.63 & 221.31 & 186.94 \\
\hline$\Sigma$ n-3 PUFA & $2.43 \pm 0.15^{x}$ & $5.17 \pm 0.60^{2}$ & $3.54 \pm 0.58^{z}$ & 203.71 & 433.40 & 296.76 \\
\hline$\sum$ n-6 PUFA/ $\Sigma$ n-3 PUFA & $11.85 \pm 0.8^{\mathrm{a}}$ & $4.25 \pm 0.70^{c}$ & $6.95 \pm 1.30^{\mathrm{b}}$ & 11.85 & 4.25 & 6.95 \\
\hline
\end{tabular}

$\Sigma$ SFA (C14:0+C15:0+C16:0+C17:0+C18:0+C20:0+C22:0)

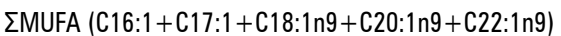

¿n-6 PUFA (C18:2n6+C18:3n6+C20:2n6+C20:3n6+C20:4n6+C22:2n6)

$\mathrm{Tr}^{*}=$ in trace

a, b, c $(P<0.05) ;{ }^{x, z}(P<0.01) ;{ }^{A, B}, C(P<0.001)$

Dietary treatments: $\mathrm{C} 2=5 \%$ of $\mathrm{SO}, \mathrm{E} 3=1.5 \%$ of RO $+3.5 \%$ of FO; $\mathrm{E} 4=3.5 \%$ of $\mathrm{RO}+1.5 \%$ of FO

The eggs from a conventional breeding are naturally poor in the ALA and do not contain the EPA and DHA essential for humans. The best EPA and DHA sources are the fish oil and seaweed (Kralik et al., 2020a; Kralik et al., 2020b). ALA is found in the flaxseed oil and is metabolically converted into the EPA and DHA. Basmacioglu et al. (2003) investigated the addition of fish oil (1.5\%), flaxseed (4.32\%), and their combination. The content of total n-3 PUFAs was highest in the laying hens fed with a diet containing the fish oil and flaxseed $(7.5 \%)$, while the $\Sigma n-6$ PUFA/ $\Sigma n-3$ PUFA ratio was very favorable (2.49). Promila et al. (2017) fed the groups of the laying hens with the diets containing 1.0, 2.0, 2.5, $3.0,3.5$, and $4.0 \%$ of linseed oil. They found out a significant cholesterol and saturated fatty acids reduction in egg yolks. The ALA increased in the yolk lipids from 1.52 to $9.79 \%$ in the total fatty acids. Bourre (2004) stated that the flaxseed and fish oil use can increase the ALA by 1-12 times and n-3 PUFA by 2-5 times. When exclusively using the fish oil in the laying hens' feeding, the egg yolk lipids' ALA can be increased by 4-8 times and the n-3 PUFA by 2-6 times. The results of a study by Zotte et al. (2015) and Ehr et al. (2017) are in line with the results of the aforementioned authors, as well as with those from our former research (Kralik et al., 2017b). Ceylan et al. (2011) fed the laying hens with the diets containing sunflower, fish, flaxseed and rapeseed oil $(1.5 \%$ and $3 \%)$. A fatty acid content was affected by a nutritional treatment. A significant interaction $(P<0.05)$ was found out between a source and the oil share in the feed and the eggs fatty acid profile. Linolenic acid was most prevalent $(5.45 \%)$ in the flaxseed treatments and the DHA in the fish oil treatments (1.64\%). The results of our research are also affected by the oil source and concentration. Zaheer et al. (2015) pointed out out that designed eggs can be considered a new type of the functional product. Hudečková et al. (2012) added 3\% of flaxseed oil into the laying hens' feed instead of the soybean oil (control).

The egg analysis demonstrated that the eggs from the experimental group contained a lower concentration of $n-6$ PUFA and a higher concentration of n-3 PUFA (ALA 0.82: $5.63 \%$, EPA $0.02: 0.13 \%$ and DHA $1.09 \%$ : 1.63\%). Aguillón-Páez et al. (2020) found out that adding the flaxseed $(13.5 \%)$ instead of sunflower seeds into the laying hens' feed has increased the n-3 PUFA $(0.99 \%$ : $6.92 \%)$ concentration and has decreased the $n-6 / n-3$ PUFA ratio, without affecting the laying hens' (22.4 : 2.2) production performance. Promila et al. (2017) supplemented the laying hens' diet with $1,2,2.5,3,3.5$, and $4 \%$ of the flaxseed oil and found out an egg cost decrease, an egg production increase, and the n-3 PUFA concentration increase in egg lipids. Linolenic acid was increased from $0.52 \%$ to $9.79 \%$, and the $n-6 / n-3$ PUFA ratio was decreased from 8.46 to 1.79 . These results are in consent with those by Oliveira et al. (2010) and Omar et al. (2014). Brown et al. (2018) found out that the laying hens' diet supplemented with the flaxseed oil did not affect either the external or the internal egg quality, except the yolk color.

Weill et al. (2002) found out that $5 \%$ of the extruded flaxseed in the hens' feed could increase the n-3 PUFA share to $258.2 \mathrm{mg} / \mathrm{egg}$ unlike the control group, where the n-3 PUFA increase was $67.3 \mathrm{mg} / \mathrm{egg}$, although the $\mathrm{n}-6$ PUFA content did not change. The $\Sigma \mathrm{n}-6 / \Sigma \mathrm{n}-3$ PUFA ratio decreased 3.6 times, and the LA/ALA ratio decreased 5.7 times. In our study, while using the flaxseed oil, the $n-6 / n-3$ PUFA ratio decreased by 3.14 , i.e., 3.76 times when compared to the control (C1) group, being identical to the results of Weill et al. (2002) and Laca et al. (2009). Simopoulos and Salem (1989) reported that the Greek free-range eggs contained $530 \mathrm{mg} / 100$ 
$\mathrm{g}$ of $\mathrm{n}-3$ PUFA per egg, while the conventional ones contained only $52 \mathrm{mg} / 100 \mathrm{~g}$ per egg. Stibilj et al. (1999) reported the lower values for Slovenian eggs (334-380 $\mathrm{mg} / 100 \mathrm{~g}$ DHA and $27-31 \mathrm{mg} / 100 \mathrm{~g}$ EPA). When the rapeseed oil was used in the laying hens' diet, the $\Sigma n-6 /$ $\Sigma$ n-3 PUFA ratio decreased in the yolk lipids by 2.79 , i.e., 1.71 times when compared to the control (C2) group. Brettschneider et al. (2006) reported the use of heat-treated rapeseed $(0 ; 7.5 ; 15.0 ; 22.5$ and $30.0 \%)$ in laying hens' diet and its effect on the fatty acid content in egg yolks. The authors found out that the content of n-6 PUFA (C18:2 + C20:4) and the n-3 PUFA (C18:3 + C20: 5 + C20:6) increased by $59 \%$, i.e., $142 \%$ with $30 \%$ of rapeseed addition in relation to the control group. The higher levels of rapeseed can be used in the laying hens' diet in case when a variety does not contain glycosinolates (Jeroch, 2005). Trsziszka et al. (2011) found out the following shares while using the flaxseed and fish oil in the laying hens' diet: ALA 3.25\%, EPA $0.19 \%$, i.e., DHA 2.12\%, which is an increase by $3.16,19.0$, and 7.48 times when compared to a standard egg. These results are consistent with our results with regard to the egg design success.

Ceylan et al. (2011) when using $3 \%$ fish oil in laying hens diet obtained 3.16\% DHA (in total FA) in egg yolks, compared to $1.71 \%$ DHA when using rapeseed oil. These results are consistent with our knowledge. Gómez (2003) pointed out that polyunsaturated fatty acids were proned to oxidation, due to several double bonds, and lipids were faster broken down in eggs. Faitarone et al. (2016) found out that the addition of $5 \%$ of the flaxseed oil to the laying hens' diets has significantly oxidized the egg lipids, being consistent with Gómez's (2003) and Cherian's (2008) results.

Petrović et al. (2012) attained the $\Sigma n-6 / \Sigma n-3$ PUFA ratio $3: 1$ while using $4 \%$ of the flaxseed oil in the laying hens' diet, being close to our results. Our research has demonstrated that the usage of flaxseed and fish oil can obtain the $\Sigma n-3$ PUFA of $6.51 \%$, i.e., $8.30 \%$ in the total fatty acids (Table 4). The rapeseed and fish oil use resulted in the $\Sigma$ n-3 PUFA increase from $2.43 \%$ to $5.17 \%$, i.e., $3.54 \%$ in the total fatty acids (Table 5 ).

\section{CONCLUSION}

Two experiments have been conducted concerning an effect of the vegetable oils' (flaxseed and rapeseed) combination with the fish oil in the laying diets' on the fatty acids profile, especially the content of n-3 PUFA in the egg yolk lipids. A statistically significant higher $\Sigma n-3$ PUFA was detected in the experimental groups E1 and E2 when compared to the control C1 group $(6.51 \%$ and $8.30 \%: 2.42 \%, \mathrm{P}<0.001$ ) in the $1^{\text {st }}$ experiment with the flaxseed oil. The experimental groups of eggs E3 and E4 also contained statistically significantly more $\Sigma$ n-3 PUFA (5.17\% and $3.54 \%)$ when compared to the control C2 group $(2.43 \%, \mathrm{P}<0.01)$ in the $2^{\text {nd }}$ experiment with the rapeseed oil. The efficiency of egg enrichment with the n-3 PUFA was higher when using the flaxseed oil than the rapeseed oil in the laying hens' diets. A narrower $\Sigma \mathrm{n}-6 / \Sigma \mathrm{n}-3$ PUFA ratio (3.08 and 2.57) was obtained in the eggs with the groups E1 and E2 than in the E3 and E4 groups (4.26 and 6.03) when compared to the control groups C1 and C2 (9.67 and 11.85), whereas the differences were statistically significant $(\mathrm{P}<0.05)$. The fatty acid profile in the diets influenced the fatty acid profile in the egg yolks of all groups.

\section{ACKNOWLEDGEMENTS}

This study is supported by the European Structural and Investment Fund's grant for the Croatian National Scientific Center of Excellence for Personalized Health Care (grant \#KK.01.1.1.01.0010) and by the Ministry of Science and Education of the Republic of Croatia.

\section{REFERENCES}

1. Aguillón-Páez, Y. J., Romero, L. A., \& Diaz, G. J. (2020). Effect of full-fat sunflower or flaxseed seeds dietary inclusion on performance, egg yolk fatty acid profile and egg quality in laying hens. Animal Nutrition, 6(2), 179-184. https://doi.org/10.1016/j.aninu.2019.12.005

2. Basmacioglu, H., Cabuk, M., Unal, K., Ozkan, K., Akkan, S., \& Yalcin, H. (2003). Effects of dietary fish oil and flax seed on cholesterol and fatty acid composition of egg yolk and blood parameters of laying hens. South African Journal of Animal Science, 33(4), 266-273.

https://doi.org/10.4314/sajas.v33i4.3776

3. Bourre, J. M. (2004). Roles of unsaturated fatty acids (especially omega-3 fatty acids) in the brain at various ages and during ageing. Journal of Nutrition, Health \& Aging, 8(3): 163-174.

4. Brelaz, K. C. B. T. R., Cruz, F. G. G., Brasil, R. J. M., Silva, A. F., Rufino, J. P. F., Costa, V. R., \& Viana Filho, G. B. (2019). Fish waste oil in laying hens* diets. Brazilian Journal of Poultry Science, 21(4).

https://www.scielo.br/pdf/rbca/v21n4/1516-635X-rbca21-04-eRBCA-2019-1069.pdf

5. Brettschneider, J. G., Jankowski, J., Pikul, J., Kozłowski, K., \& Jeroch, H. (2006). Influence of graded levels of rape seed in the diets of commercial brown layers on egg quality. Veterinarija ir Zootechnika, 35(57), 38-40.

6. Brown, C. A., Hamidu, J. A., Adomako, K., \& Okai, M. A. (2018). Effects of omega-3 fatty acids enrichment with flaxseed oil and egg storage duration on egg quality. Livestock Research for Rural Development, 30(3). http://Irrd.cipav.org.co/Irrd30/3/jaha30045.html

7. Bubel, F., Dobrzański, Z., Bykowski, P., PatkowskaSokoła, B., \& Trziszka, T. (2011). Enrichment of hen eggs with omega-3 polyunsaturated fatty acids-physiological and nutritional aspects. Acta Scientiarum PolonorumMedicina Veterinaria, 10(3), 5-18.

8. Burdge, G. C. (2006). Metabolism of $\alpha$-linolenic acid in humans. Prostaglandins, leukotrienes and essential fatty acids, 75(3), 161-168.

https://doi.org/10.1016/j.plefa.2006.05.013 
9. Ceylan, N., Ciftçi, I., Mizrak, C., Kahraman, Z., \& Efil, H. (2011). Influence of different dietary oil sources on performance and fatty acid profile of egg yolk in laying hens. Journal of Animal and Feed Sciences, 20(1), 71-83. https://doi.org/10.22358/jafs/66159/2011

10. Cherian, G. (2008). Egg quality and yolk polyunsaturated fatty acid status in relation to broiler breeder hen age and dietary n-3 oils. Poultry Science, 87(6), 1131-1137. https://doi.org/10.3382/ps.2007-00333

11. Csapó, J., L. Sugár, A. Horn, Jné Csapó (1986): Chemical composition of milk from red deer, roe and fallow deer kept in captivity. Acta Agronomica Hungarica, 3-4; 359372

12. Ehr, I. J., Persia, M. E., \& Bobeck, E. A. (2017). Comparative omega-3 fatty acid enrichment of egg yolks from first-cycle laying hens fed flaxseed oil or ground flaxseed. Poultry Science, 96(6), 1791-1799. https://doi.org/10.3382/ps/pew462

13. Faitarone, A. B. G., Garcia, E. A., Roça, R. O., Andrade, E. N., Vercese, F., \& Pelícia, K. (2016). Yolk color and lipid oxidation of the eggs of commercial white layers fed diets supplemented with vegetable oils. Brazilian Journal of Poultry Science, 18(1), 9-16. http://dx.doi.org/10.1590/1516-635X1801009-016

14. Fraeye, I., Bruneel, C., Lemahieu, C., Buyse, J., Muylaert, K., \& Foubert, I. (2012). Dietary enrichment of eggs with omega-3 fatty acids: A review. Food Research International, 48(2), 961-969. https://doi.org/10.1016/j.foodres.2012.03.014

15. Fröhlich, A., \& Rice, B. (2005). Evaluation of Camelina sativa oil as a feedstock for biodiesel production. Industrial Crops and Products, 21(1), 25-31. https://doi.org/10.1016/j.indcrop.2003.12.004

16. Gómez, M. E. D. L. D. (2003). Modulação da composição de ácidos graxos poliinsaturados ômega 3 de ovos e tecidos de galinhas poedeiras, através da dieta. I. Estabilidade oxidativa (Doctoral dissertation, Universidade de São Paulo). DOI: 10.11606/T.9.2003.tde-02062003-150007

17. Hudečková, P., Rusníková, L., Straková, E., Suchý, P., Marada, P., \& Macháček, M. (2012). The effect of linseed oil supplementation of the diet on the content of fatty acids in the egg yolk. Acta Veterinaria Brno, 81(2), 159-162.

18. Hussein, N., Ah-Sing, E., Wilkinson, P., Leach, C., Griffin B. A., \& Millward, D. J. (2005). Long-chain conversion of [13C] linoleic acid and $\alpha$-linolenic acid in response to marked changes in their dietary intake in men. Journal of Lipid Research, 46(2), 269-280.

19. Jeroch, H. (2005). Futterwert von Rapsfuttermitteln und deren Einsatz in der Fütterung landwirtchaftlicher Nutztiere. In Proceedings $12^{\text {th }}$ International Conference KRMIVA, Opatija, Croatia, June 6-9, 207-217.

20. Kralik, G., Bogut, I., Škrtić, Z., \& Gajčević, Z. (2005). Effect of preparation rich in omega-3 acids on the production and quality of eggs. In Proceedings of $\mathrm{X}^{\text {th }}$ European Symposium on the Quality of Eggs and Egg Products (CD) (pp. 23-26).

21. Kralik, G., Gajčević, Z., \& Škrtić, F. (2008a). The effect of different oil supplementations on laying performance and fatty acid composition of egg yolk. Italian Journal of Animal Science, 7(2), 173-183.

https://doi.org/10.4081/ijas.2008.173

22. Kralik, G., Škrtić, Z., Suchý, P., Straková, E., \& Gajčević, Z. (2008b). Feeding fish oil and linseed oil to laying hens to increase the n-3 PUFA in egg yolk. Acta Veterinaria Brno, 77(4), 561-568. https://doi.org/10.2754/avb200877040561

23. Kralik, Z., Grčević, M., Kralik, G., Hanžek, D., \& Zelić, A. (2017a). Quality of table eggs on the Croatian market. Poljoprivreda, 23(1), 63-68. https://doi.org/10.18047/poljo.23.1.10

24. Kralik, G., Kralik, Z., Straková, E., Grčević, M., \& Hanžek, D. (2017b). Enriched eggs as a source of n-3 polyunsaturated fatty acids for humans. Acta veterinaria (Brno), 86(3), 293-301. https://doi.org/10.2754/avb201786030293

25. Kralik, G., Kralik, Z., Grčević, M., Kralik, I., \& Gantner, V. (2018). Enrichment of table eggs with functional ingredients. Journal of Central European Agriculture, 19(1), 72-82. https://doi.org/10.5513/JCEA01/19.1.2025

26. Kralik, Z., Kralik, G., Grčević, M., Hanžek, D., \& Margeta, P. (2020a). Microalgae Schizochytrium limacinum as an alternative to fish oil in enriching table eggs with $n-3$ polyunsaturated fatty acids. Journal of the Science of Food and Agriculture, 100(2), 587-594. https://doi.org/10.1002/jsfa.10052

27. Kralik, G., Grčević, M., Hanžek, D., Margeta, P., Galović, 0. \& Kralik, Z. (2020b). Feeding to produce n-3 fatty acid-enriched table eggs. The Journal of Poultry Science, 57(2), 138-147. https://doi.org/10.2141/jpsa.0190076

28. Laca, A., Paredes, B., \& Díaz, M. (2009). Quality characteristics of $n-3$ polyunsaturated fatty acid-enriched eggs.JournalofAnimalandFeed Sciences, 18(1), 101-112. https://doi.org/10.22358/jafs/66373/2009

29. Margeta, P., Kralik, G., Grčević, M., Hanžek, D., \& Kralik, Z. (2019). Importance of sensory evaluation in assessment of egg quality. Poljoprivreda, 25(1), 56-63. https://doi.org/10.18047/poljo.25.1.8

30. Mariod, A. A., Mukhtar, M. A. E., Salih, M. E., \& Herwan, T. (2015). Effect of addition of fish oil on the performance parameters of laying hens and the fatty acid composition of their egg yolk. American Journal of Food Science and Health, 1(2), 38-42.

31. Meyer, B. J., Mann, N. J., Lewis, J. L., Milligan, G. C. Sinclair, A. J., \& Howe, P. R. (2003). Dietary intakes and food sources of omega- 6 and omega-3 polyunsaturated fatty acids. Lipids, 38(4), 391-398.

https://doi.org/10.1007/s11745-003-1074-0

32. Miranda, J. M., Anton, X., Redondo-Valbuena, C., RocaSaavedra, P., Rodriguez, J. A., Lamas, A., ... \& Cepeda, A. (2015). Egg and egg-derived foods: effects on human health and use as functional foods. Nutrients, 7(1), 706729. https://doi.org/10.3390/nu7010706

33. Oliveira, D. D., Baião, N. C., Cançado, S. V., Grimaldi, R., Souza, M. R., Lara, L. J. C., \& Lana, A. O. (2010). Effects of lipid sources in the diet of laying hens on the 
fatty acid profiles of egg yolks. Poultry Science, 89(11), 2484-2490.

https://doi.org/10.3382/ps.2009-00522

34. Omar, A. S., Ramadan, N. A., Bahakaim, A. S. A., Osman, S. M., \& Abdel Malak, N. Y. (2014). Effect of using different levels of fish oil, linseed oil and their combination in layer diets on egg omega 3 enrichment. Journal of Animal and Poultry Production, 5(12), 759774.

35. Petrović, M., Gačić, M., Karačić, V., Gottstein, Ž., Mazija, H., \& Medić, H. (2012). Enrichment of eggs in n-3 polyunsaturated fatty acids by feeding hens with different amount of linseed oil in diet. Food Chemistry, 135(3), 1563-1568.

https://doi.org/10.21608/jappmu.2014.70770

36. Promila, N. K., Sihag, S., Shunthwal, J., Verma, R., \& Baloda, S. (2017). Effect of linseed oil supplementation on hen day egg production, body weight, egg shape index, economics and egg quality in layers. International Journal of Current Microbiology and Applied Sciences 6(11), 2005-2016. https://doi.org/10.20546/ijcmas.2017.611.239

37. Scheideler, S. N. \& Lewis, N. (1997). Omega eggs: a dietary source of n-3 fatty acids. Nebraska Facts, NF97354. http://digitalcommons.unl.edu/extensionhist/463/

38. Shapira, N. (2010). Every egg may have a targeted purpose: toward a differential approach to egg according to composition and functional effect. World's Poultry Science Journal, 66(2), 271-284. https://doi.org/10.1017/S0043933910000322

39. Simopoulos, A. P., \& Salem, J. N. (1989). N-3 fatty acids in eggs from range-fed Greek chickens. The New England Journal of Medicine, 321(20), 1412-1412. https://doi.org/10.1056/NEJM198911163212013
40. Statistica for Windows version 13.3., StatSoft Inc. 2017.

41. Stibilj, V., Koman Rajšp, M., \& Holcman, A. (1999). Fatty acid composition of eggs enriched with omega-3 fatty acids on the market. Zbornik Biotehniške fakultete Univerze v Ljubljani, Kmetijstvo, Zootehnika, 74(2), 27-36.

42. Trziszka, T., Dobrzański, Z., Kaźmierska, M., Tronina, Ł., \& Skiba, M. (2011). Effect of dietary humic-fatty preparations on egg quality in Lohmann Brown hens. Archiv für Geflügelkunde, 75(2), 84-90.

43. Weill, P., Schmitt, B., Chesneau, G., Daniel, N., Safraou, F., \& Legrand, P. (2002). Effects of introducing linseed in livestock diet on blood fatty acid composition of consumers of animal products. Annals of Nutrition and Metabolism, 46(5), 182-191. 82-191. https://doi.org/10.1159/000065405

44. Yalçın, H., \& Ünal, M. K. (2010). The enrichment of hen eggs with $\omega-3$ fatty acids. Journal of Medicinal Food, 13(3), 610-614. https://doi.org/10.1089/jmf.2008.0024

45. Zaheer, K. (2015). An updated review on chicken eggs: production, consumption, management aspects and nutritional benefits to human health. Food and Nutrition Sciences, 6(13), 1208-1220. https://doi.org/10.4236/fns.2015.613127

46. Zotte, A. D., Andrighetto, I., Giaccone, V., \& Marchesini, G. (2015). Dietary enrichment of n-3 PUFA for laying hens: effect of different sources on production, composition and quality of eggs. Animal Science Papers \& Reports, 33(4): 411-424. 


\section{UTJECAJ BILJNIH ULJA I RIBLJEGA ULJA NA PROFIL MASNIH KISELINA U ŽUMANJCIMA JAJA}

\section{SAŽETAK}

$U$ radu su prikazani rezultati istraživanja uporabe lanenoga sjemena (LO) i sjemena uljane repice (RO) u kombinaciji s ribljim uljem (FO) u hranidbi nesilica te utjecaj na profil masnih kiselina žumanjaka ( $\sum n-6$ PUFA i $\sum n-6$ PUFA/ $\sum n-3$ PUFA). Hranidbeni tretmani bili su sljedeći: C1, C2 = kontrola (5\% sojinoga ulja SO), E1 = $1,5 \%$ LO + 3,5\% FO, E2 = 3,5\% LO + 1,5\% FO, E3 = 1,5\% RO + 3,5\% FO, E4 = 3,5\% RO + 1,5\% FO. Krmne smjese za nesilice bile su izbalansirane na bazi 17\% sirovih bjelančevina i 11,5 MJ/kg ME, a omjer n-6/n-3 PUFA u smjesama bio je sljedeći: C1 13,64; C2 13,10; E1 2,63; E2 1,53; E3 4,84 i E4 6,21. Kombinacija lanenoga ulja i ribljeg ulja u hrani utjecala je na omjer n-6/n-3 PUFA, što ga čini užim u usporedbi s kombinacijom repičina i ribljeg ulja. Kontrolne smjese C1 i C2 sadržavale su samo ALA 3,12 i 4,08\%, bez EPA i DHA masnih kiselina. Analiza profila masnih kiselina u žumanjcima pokazala je da jaja, uz ALA, sadrže 1,16 i 1,26\% DHA, što znači da se, iako u malim količinama, DHA sintetizirala $i$ odlagala u jajima nesilice. U jajima pokusnih skupina utvrđeni su sljedeći udjeli n-3 PUFA: E1 6,51\%, E2 8,30\%, E3 5,17\% i E4 3,54\%. Omjer n-6/n-3 PUFA u žumanjcima smanjen je s 9,67 i 11,85 (kontrolne skupine) na 3,08, odnosno na 2,57 kod tretmana s lanenim sjemenom i ribljim uljem, to jest na 4,25 i 6,95 kod tretmana s repičinim i ribljim uljem. Istraživanja su pokazala učinkovitije taloženje n-3 PUFA u žumanjcima E1 i E2 skupina, iako je ALA bila najzastupljenija u ukupnim n-3 PUFA.

Ključne riječi: jaje, FA, ALA, EPA, DHA, n-6/n-3 PUFA ratio

(Received on September 28, 2020; accepted on November 11, 2020 - Primljeno 28. rujna 2020.; prihvaćeno 11. studenoga 2020.) 